\title{
Sistem Pakar untuk Mendeteksi Kerusakan Jaringan Internet pada Indihome di Pematangsiantar
}

\author{
Muhammad Sya' ${ }^{\prime}{ }^{* 1}$, Indra Gunawan ${ }^{2}, \operatorname{Irawan}^{3}$, Poningsih $^{4}$, Rafiqa Dewi ${ }^{5}$ \\ 1,2,3,4,5 Teknik Informatika, STIKOM Tunas Bangsa Pematangsiantar, Indonesia \\ Email: ${ }^{1}$ muhammadsyai07@gmail.com, ${ }^{2}$ indra@amiktunasbangsa.ac.id, \\ 3irawan@amiktunasbangsa.ac.id, ${ }^{4}$ poningsih@amiktunasbangsa.ac.id, ${ }^{5}$ rafika.atb@gmail.com
}

\begin{abstract}
Abstrak
Pendeteksian gangguan jaringan internet indihome seringkali membutuhkan waktu yang lama. Hal ini dikarenakan tidak semua pengguna jaringan internet indihome mengerti penanganan gangguan pada jaringan internet indihome. Selain itu administrator Indihome sendiri terkadang membutuhkan waktu yang tidak sedikit dalam mendeteksi gangguan pada jaringan internet. Tujuan dari penelitian ini adalah membangun sistem pakar untuk mendeteksi gangguan jaringan internet indihome. Sistem pakar ini dapat digunakan pengguna indihome untuk membantu mendeteksi gangguan pada jaringan dan dapat dijadikan sebagai asisten pakar oleh administrator indihome. Sistem Pakar ini dibangun menggunakan metode Forward Chaining. Hasilnya direpresentasikan ke dalam Knowledge Based Table yang selanjutnya digunakan untuk pembangunan sistem pakar. Metode ini cocok dipakai di sistem pakar yang mendiagnosis suatu yang belum pasti dengan menggunakan perhitungan yang akurat untuk memastikan nilai keyakinannya. Manfaat yang didapat dari sistem pakar yang mampu melaksanakan diagnosis dengan singkat, tepat dan akurat kepada gejala kerusakan yang ada diharapkan bisa membantu karyawan dalam menyampaikan solusi dan penanganan secara akurat dari kerusakan yang terjadi pada jaringan internet indihome.
\end{abstract}

Kata kunci: Forward Chaining, Kerusakan Jaringan Internet, Sistem Pakar

\begin{abstract}
Detection of indihome internet network disturbances often takes a long time. This is because not all indihome internet network users understand the handling of disturbances on the indihome internet network. In addition, Indihome administrators themselves sometimes need a lot of time to detect disturbances on the internet network. The purpose of this research is to build an expert system to detect indihome internet network disturbances. This expert system can be used by indihome users to help detect network disturbances and can be used as an expert assistant by indihome administrators. This Expert System was built using the Forward Chaining method. The results are represented in a Knowledge Based Table which is then used for the development of an expert system. This method is suitable for use in expert systems that diagnose something that is not certain by using accurate calculations to ensure the confidence value. The benefits obtained from an expert system that is able to carry out a short, precise and accurate diagnosis of the existing damage symptoms are expected to assist employees in delivering solutions and accurate handling of the damage that occurs on the indihome internet network.
\end{abstract}

Keywords: Forward Chaining, Internet Network Damage, Expert System

\section{PENDAHULUAN}

Di era perubahan teknologi dan informasi semakin meningkat, kebutuhan akan akses informasi adalah hal yang sangat penting sehingga membuat teknologi menjadi kebutuhan pokok bagi semua orang. Salah satu teknologi yang perkembangannya sangat cepat ialah Jaringan Internet, "Lembaga riset digital marketing memperkirakan pada 2018 jumlah pengguna aktif Jaringan Internet Indihome di Pematangsiantar lebih dari 10 juta orang."(http://kominfo.go.id) dengan perkembangannya yang sangat cepat maka vendor Indihome pun semakin memberikan fasilitas untuk konsumennya dengan menggunakan sistem Jaringan Koneksi Internet yang memiliki batasan Kecepatan akses data sesuai dengan kebutuhan konsumen. Ada beberapa jenis layanan jaringan internet yang bisa digunkan yaitu, seperti serat optic, wireless, satelit komumikasi. Kegunaan pengguna jaringan semakin berkembang 
dengan pesat seiring dengan teknologi jaringan yang berkembang sehingga sudah sebaiknya suatu organisasi atau lembaga mulai memakai penggunaan jaringan Internet.

Pada penelitian sebelumnya tentang Sistem Pakar Diagnosis Kerusakan Jaringan Local Area Network (LAN) Menggunakan Metode Forward Chaining yang dilakukan oleh Rizky [1] menjadikan referensi penulis dalam membuat penelitian ini. Penelitian dibidang kesehatan sebelumnya oleh Rini Agustina yang meneliti sistem pakar diagnosa penyakit akibat asap rokok. Hasil penelitian menunjukkan sistem pakar mampu mendiagnosa penyakit akibat asap rokok pada perokok pasif sesuai dengan pendapat pakar [2].

Setiap Instansi Penyedia Layanan Internet tersebut memiliki kelebihan dan kekurangannya masingmasing dari segi alat, kualitas dan harga yang berbeda-beda pula. Kestabilan jaringan yang dimiliki indihome tidak bisa menjadi patokan kalau tidak akan terjadi kerusakan atau gangguan. Permasalahan sering terjadi pada sistem Koneksi Internet bisa timbul tidak hanya saat pembangunan jaringan tersebut tetapi bisa terjadi saat penggunaannya seperti koneksi yang tiba-tiba putus, tidak dapat share data, tidak dapat mencetak pada printer yang ada didalam jaringan, dan lain-lain. Permasalahan permasalahan diatas sering terjadi karena perangkat lunak (software) rusak dan juga akibat kurang pemahaman oleh pengguna jaringan tersebut. Hal tersebut sangat berdampak kepada administrator jaringan kesulitan dalam mendiagnosa gangguan pada jaringan Internet secara praktis dan tepat waktu pada permasalahan yang perlu segera diselesaikan

Sistem Pakar sebagai Alat Bantu Pembelajaran Troubleshooting Jaringan Internet. penelitian ini memiliki tujuan membangun sistem pakar untuk mendeteksi gangguan jaringan Internet Indihome dengan metode Forward Chainning. Sistem pakar ini menggambarkan sebuah program komputer yang berbasis representasi pengetahuan oleh seorang atau beberapa pakar dimana program komputer ini bermaksud menyelesaikan persoalan atau mendukung dalam pembuatan ketetapan. Atas penelitian ini pemahaman yang dimiliki pakar didalam hal ini seorang Techniqual Support Jaringan Komputer ditransfer dalam knowledge based yang nantinya akan dijadikan representasi keahlian dalam sistem pakar yang akan dirancang.

Penggunaan metode Forward Chainning ini dikarenakan metode ini menjalankan pelacakan secara runtut maju dimulai dari pengamatan premis menuju pada kesimpulan akhir sehingga tepat dipergunakan dalam persoalan jaringan tersebut. Dengan demikian pihak Provider Indihome dapat memberi perawatan lebih serta antisipasi terhadap Kerusakan Jaringan Internet kedepannya.

\section{TINJAUAN PUSTAKA}

\subsection{Sistem Pakar}

Sistem Pakar (Expert System) ialah suatu cabang dari sebuah kecerdasan buatan. Sistem pakar memiliki definisi yaitu sistem yang berupaya mengadopsi pemahaman manusia pada komputer, sehingga komputer bisa menuntaskan masalah seperti yang biasa dilakukan oleh para ahli [2].

Sistem Pakar adalah salah satu metode yang terdapat dalam kecerdasan buatan yang digunakan untuk mendiagnosis kesalahan sistem dan sebagai pemecahan masalah [3].

\subsection{Forward Chaining}

Forward chaining merupakan proses perunutan yang dimulai dengan menampilkan kumpulan data atau fakta yang meyakinkan menuju konklusi akhir. Runut maju dimulai dari premis-premis atau informasi masukan (if) dahulu kemudian menuju kesimpulan atau derived information(then) [4].

Forward Chaining merupakan sebuah metode yang ada dalam sebuah sistem pakar yang menggunakan cara goal driven. Dimana prosesnya dimulai dengan menganalisa informasi yang telah diinputkan oleh user yang nantinya akandisesuaikan denga rule yang telah disusun berdasarkan basis pengetahuan dengan aturan IF-THEN. Dalammetode ini sangat diperlukan sebuah inputan data yang nantinya akan digunakan untuk memulai sebuah proses inferensi [5]. 


\subsection{Web HTML}

Website atau situs juga dapat diartikan sebagai kumpulan halaman yang menampilkan informasi data teks, data gambar diam atau gerak, data animasi, suara, video dan atau gabungan dari semuanya, baik yang bersifat statis maupun dinamis yang membentuk satu rangkaian bangunan yang saling terkait dimana masing-masing dihubungkan dengan jaringanjaringan halaman (hyperlink) [6].

HTML (Hypertext Markup Language) merupakan suatu bahasa pemrograman yang berbentuk kumpulan code atau skrip yang berfungsi untuk membuat sebuah halaman web. HTML merupakan jenis bahasa pemrograman web yang bersifat client-side scripting maksudnya bahasa pemrograman yang tidak perlu di compile oleh web server, melainkanbisa langsung berjalan di browser [7].

HTML merupakan bahasa yang digunakan untuk menulis halaman website, dirancang untuk tidak tergantung pada suatu sistem operasi tertentu [8].

1. MySQL

MySQL merupakan program pengelolaan database berbasis Structured Query Language (SQL) yang menawarkan database yang stabil dalam penyimpanan data [9].

2. XAMPP

Xampp merupakan perangkat lunak gratis yang merupakan kompilasi dari beberapa aplikasi. Xampp berfungsi sebagai server yang berdiri sendiri (localhost), yang terdiri atas program Apache HTTP Server, MySQL database, dan penerjemah bahasa yang ditulis dengan bahasa pemrograman PHP dan Perl [10].

\section{METODE PENELITIAN}

Metodologi penelitian merupakan suatu prosedur atau langkah yang dilakukan oleh peneliti dalam rangka untuk mengumpulkan suatu data atau informasi. Metodologi penelitian memiliki gambaran rancangan penelitian yang meliputi antara lain yaitu mulai dari cara mengumpulkan data, menganalisa data.

\subsection{Rancangan Penelitian}

Rancangan penelitian ini pertama kali penulis melakukan pengamatan selanjutnya mengumpulkan data setelah itu data tersebut di susun menggunakan aturan IF Then setelah itu penulis mengumpulkan diagnosas kerusakan yang terjadi, kemudian membuat kemungkinan diagnosa ke dalam tabel, setelah itu data akan diolah melalui proses perhitungan dan mengikuti langkah-langkah proses perhitungan metode Forward cainning Selanjutnya hasil perhitungan tersebut akan diaplikasikan ke web untuk melihat keakuratan hasil yang diperoleh. Rancangan penelitian dapat dilihat pada Gambar 1.

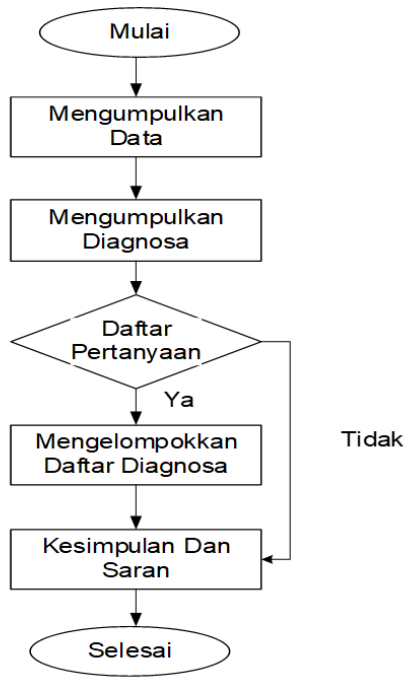

Gambar 1. Rancangan Penelitian 


\subsection{Prosedur Pengumpulan Data}

Pengumpulan data dilakukan untuk memperoleh informasi yang dibutuhkan dalam rangka mencapai tujuan penelitian. beberapa hal yang dilakukan penulis dalam mengumpulkan data dalam penelitian ini adalah penulis melihat referensi-referensi berupa buku dan jurnal untuk memudahkan penulis dalam menyelesaikan karya tulis yang dilakukan, serta melakukan wawancara langsung ke PT. Telkom Indonesia Pematangsiantar.

\subsection{Analisa Data}

Analisa dilakukan dengan data dan bukti mendukung penelitian sudah dilakukan. Dimana proses penganalisaan data dapat dilakukan setelah proses Pengumpulan data. Data yang dipakai oleh penulis untuk mendukung terlaksananya penelitian yaitu Data sekunder. Data Sekunder adalah sumber data penelitian yang diperoleh melalui media perantara atau secara tidak langsung yang berupa buku, catatan, bukti yang telah ada atau arsip baik yang dipublikasikan maupun yang tidak di publikasikan secara umum. Data yang diperoleh dari penelitian ini adalah data observasi diagnosa penyebab terjadinya kerusakan pada Indihome.

Penelitian ini menggunakan Basis Pengetahuan atau (Knowledge Base) yang mengandung pengetahuan terkait pemahaman, formulasi, dan penyelesaian masalah. Kemampuan sebuah system pakar dalam menyelesaikan sebuah masalah didapat dengan cara merepresentasikan suatu pengetahuan seorang atau beberapa orang pakar ke dalam format tertentu dan menyimpannya dalam basis pengetahuan. Sebuah sistem pakar berbasis aturan umumnya menggunakan aturan (rules) untuk merepresentasikan pengetahuan di dalam basis pengetahuannya.

Tabel 1 dibawah ini memperlihatkan keluhan-keluhan terkait layanan jaringat internet Indihome:

Tabel 1. Keluhan Pelanggan

\begin{tabular}{ccc}
\hline No & Kode Gangguan & Nama Gangguan \\
\hline 1 & G001 & Akses internet eror \\
2 & G002 & Lampu internet mati \\
3 & G003 & Bandwith hilang \\
4 & G004 & Modem tereset \\
5 & G005 & Lampu wlan mati \\
6 & G006 & Lampu kuning blink \\
7 & G007 & Lampu merah menyala \\
8 & G008 & Modem tidak menyala \\
9 & G009 & Bandwitch tidak stabil \\
10 & G010 & Terdapat pesan maintenence \\
11 & G011 & Bandwitch tidak naik \\
12 & G012 & Nama wifi tidak muncul \\
13 & G013 & Kerusakan pada kabel \\
14 & G014 & Useetv blank hitam \\
15 & G015 & \\
\hline
\end{tabular}

Berdasarkan Tabel 1 di atas ini maka dibuat tabel solusi untuk permasalahan diatas yang akan digunakan sebagai pengetahuan bagi penggunanya.

Tabel berikut memperlihatkan Solusi dari Permasalahan layanan pada Jaringan Internet Indihome dapat dilihat pada Table 2 .

Berdasarkan Tabel 2 dalam penelitian ini maka dibuat tabel rule untuk mendiagnosa permasalahan yang memakai Sistem Pakar yang akan digunakan sebagai hasil diagnosa dari keluhan Pelanggan.

Pada Tabel 3 diperlihatkan Rule dari Permasalahan layanan Jaringan Internet Indihome. 
Tabel 2. Tabel Solusi

\begin{tabular}{|c|c|c|c|}
\hline No & Kode Solusi & Nama Solusi & Solusi \\
\hline 1 & P001 & Kabel optik & $\begin{array}{l}\text { Terjadi kabel optik putus, redaman kabel tinggi, dan server } \\
\text { (odp) rusak, dan conector pada modem rusak }\end{array}$ \\
\hline 2 & P002 & $\begin{array}{l}\text { Setting } \\
\text { manual }\end{array}$ & $\begin{array}{l}\text { Terjadi kesalahan Sistem karena kesalahan pada settingan } \\
\text { manual, misalnya koneksi error, lost internet, tidak adanya } \\
\text { bandwith yang diterima }\end{array}$ \\
\hline 3 & P003 & Kabel ont & $\begin{array}{l}\text { Terjadinya gangguan pada kabel ONT seperti ada serabut } \\
\text { yang putus, kabel tidak terpasang, dan kesalahan pemasangan }\end{array}$ \\
\hline 4 & P004 & bandwitch & $\begin{array}{l}\text { Sinyal Lemah, tidak dapat mendownload dan upload Data } \\
\text { karena Bandwith yang tidak stabil }\end{array}$ \\
\hline 5 & P005 & maintenence & $\begin{array}{l}\text { adanya pemeliharaan atau maintance dari pusat indihome, } \\
\text { biasa nya akan diberi pemberitahuan kepada pengguna } \\
\text { indihome }\end{array}$ \\
\hline 6 & P006 & $\begin{array}{l}\text { Hubungi } \\
\text { call center } \\
\text { indihome }\end{array}$ & Hubungi Call center di 147 \\
\hline
\end{tabular}

Tabel 3. Tabel Rule

\begin{tabular}{ccc}
\hline Rule & IF & Then \\
\hline 1 & G03\&G08\&G013\&G018 & P01 \\
2 & G02\&G05\&G07\&G12\&G17 & P02 \\
3 & G04\&G09\&G014 & P03 \\
4 & G010\&G015\&G017 & P04 \\
5 & G01\&G06\&G011\&G016 & P05 \\
6 & G03\&G06\&G008 & P06 \\
\hline
\end{tabular}

\subsection{Alat Analisa Data}

Dalam melakukan penelitian ini penulis menggunakan Pohon Keputusan sebagai alat untuk memproses data diagnosa, Pohon Keputusan dipakai dalam membantu pada proses menggunakan sistem If Then. setelah proses pengelompokan diagnosa selesai maka selanjutnya diaplikasikan menggunakan pengujian berbasis web untuk melihat keakuratan hasil yang didapat dan akan menghasilkan sebuah solusi.

\subsection{Pemodelan Metode}

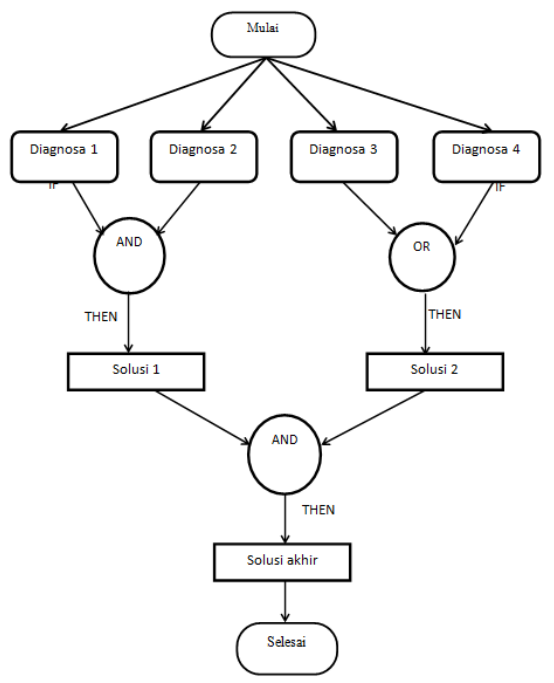

Gambar 2. Pemodelan Metode 
Setiap metode atau algoritma memiliki pemodelanya masing-masing sesuai pengerjaan, Penulis menggunakan metode Forward Chaining untuk mendiagnosa kerusakan pada jaringan Indihome. Untuk pemodelan metode Forward Chainning bisa dilihat di Gambar 2.

Berikut adalah langkah-langkah penyelesaian yang dilakukan penulis dalam menentukan diagnosa kerusakan indihome menggunakan Sistem pakar metode forrward Chainning:

1. Membuat beberapa Diagnosa pada kerusakan yang ada, misalnya diagnosa 1 sampai diagnosa 4.

2. Mencari solusi dari beberapa diagnosa dengan menerapkan if then.

3. Setelah mendapat solusi dari beberapa diagnosa, selanjutnya melakukan pelacakan diagnosa kembali untuk mendapatkan solusi akhir.

4. Setelah mendapatkan solusi akhir maka hasil diagnosa ditemuka dan kita dapat menarik kesimpulan berupa solusi dari diagnosa yang ada.

\section{HASIL DAN PEMBAHASAN}

\subsection{Pengolahan Data dan Produksi data If-Then}

Kaidah produksi dituliskan dalam bentuk jika-maka (IF-THEN). Kaidah ini dapat dikatakan sebagai hubungan implikasi dua bagian, yaitu bagian premis (jika) dan bagian konklusi (maka). Apabila bagian premis dipenuhi maka bagian konklusi juga akan bernilai benar. Suatu kaidah juga dapat terdiri atas beberapa premis dan lebih dari satu konklusi. Antara premis dan konklusi dapat berhubungan dengan "OR" atau "AND". Berdasarkan tabel keputusan dan pohon keputusan, maka kaidah aturan gangguan jaringan Internet Indihome dengan mennggunakan metode forward chaining terdapat beberapa rule berikut ini:

1. Kaidah 1: jika bandwitch hilang, lampu merah pada modem menyala, telpon tidak berfungsi, maka penyebabnya pada kabel optik (P001).

2. Kaidah 2: jika lampu internet mati, modem tereset, lampu kuning blink, bandwitch tidak naik, useetv eror 1302, maka penyebab gangguan pada setingan settingan manual (P002).

3. Kaidah 3: jika kabel patchcore putus, modem tidak menyala, kerusakan pada kabel, maka penyebab gangguan pada kabel ont (P003).

4. Kaidah 4: jika bandwitch tidak stabil,useetv maca - macat, useetv eror 1302, maka penyebab gangguan pada bandwitch (P004).

5. Kaidah 5: jika akses internet eror, lampu wlan mati, terdapat pesan maintenance, telpon dan juseetv eror, maka penyebab gangguan pada maintenence (P005).

6. Kaidah 6: jika Koneksi lemot, bandwith naik turun, dan lampu kuning blink terus menerus maka Penyebab gangguan adalah pada setingan bandwith (P006).

\subsection{Hasil Percobaan}

Implementasi sistem atau hasil Percobaan merupakan tahap menerjemahkan perancangan berdasarkan hasil analisis dalam bahasa yang mudah dimengerti oleh mesin komputer, serta penerapan perangkat lunak pada keadaan siap untuk dioperasikan. Berikut hasil implementasi sitem.

1. Halaman awal website

Halaman awal web sistem pakar ini adalah tampilan web pada saat pertama kali kita mengkakses menggunakan link Localhost/indihome. Di dalam tampilan menu beranda terdapat beberapa sub menu yang memudahkan pengguna dalam menggunakan web sistem pakar tersebut. Tampilan Halaman beranda bisa dilihat pada Gambar 3. 


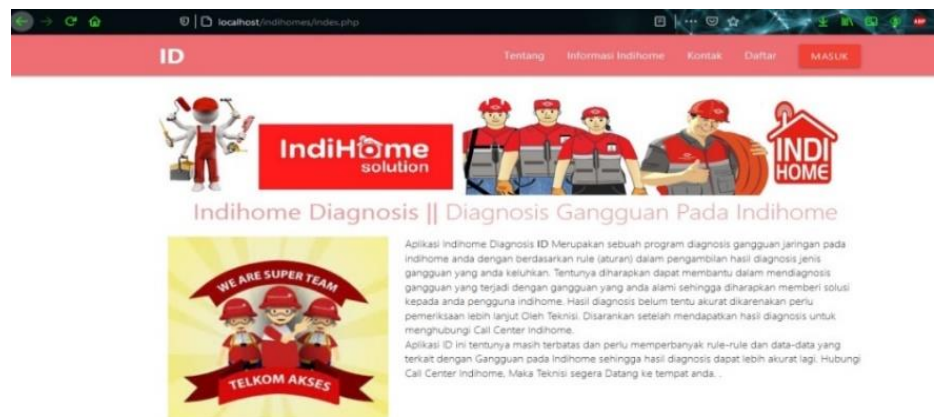

Gambar 3. Halaman Beranda

2. Halaman Untuk Konsultasi Gangguan

Halaman Konsultasi digunakan user untuk membantu mencari diagnosa atau solusi dari gangguan yang terjadi pada alat mereka. Berikut adalah tampilan konsultasi dari 2 user yang berbeda. Tampilan Halaman konsultasi dapat dilihat pada Gambar 4.

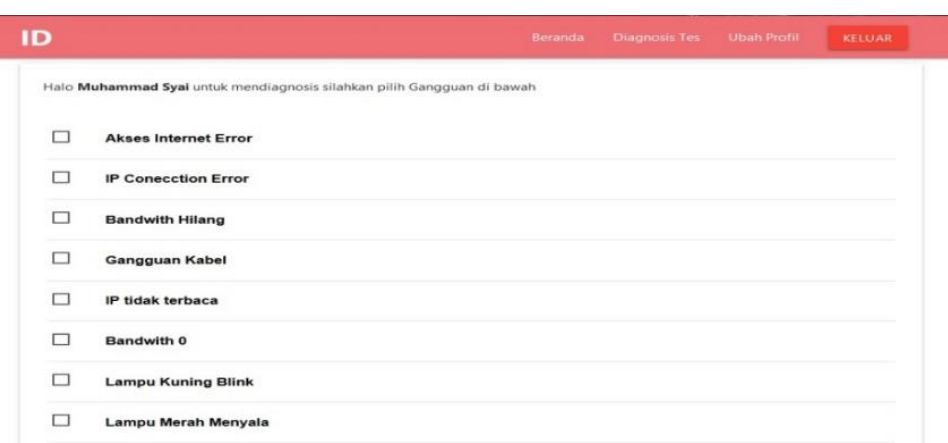

Gambar 4. Halawan Awal Konsultasi

3. Halaman Konsultasi Lanjutan

Halaman mengisi jawaban Konsultasi digunakan user untuk membantu mencari diagnosa atau solusi dari gangguan yang terjadi pada alat mereka dengan cara sistem mengajukan pertanyaaan kepada user, kemudian user akan memilih jawaban yang berkaitan dengan permasalaahan yang ada pada alat mereka. Berikut adalah tampilan konsultasi.

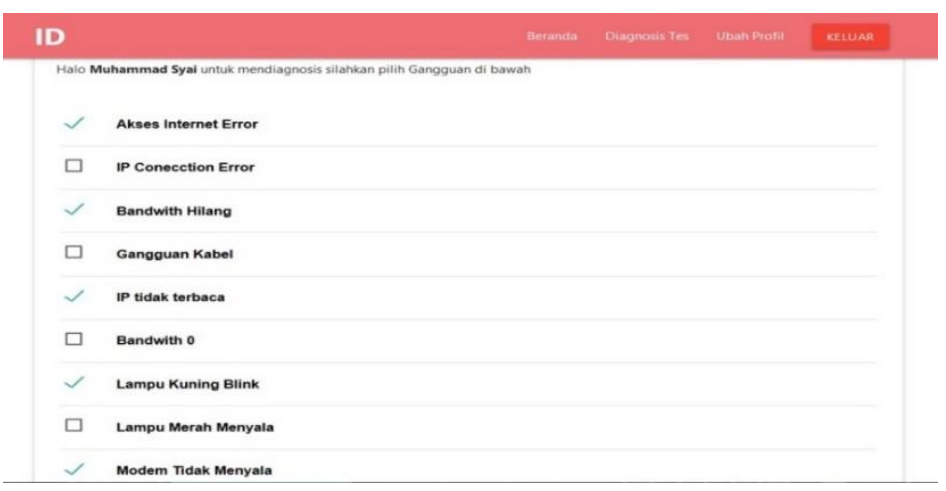

Gambar 5. Halaman Konsultasi Lanjutan

ID

Hasil Tes Diagnosis Muhammad

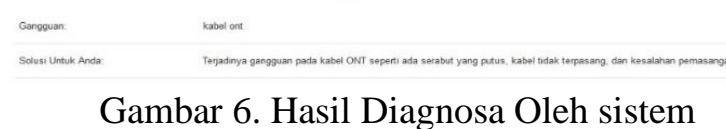


Histori Hasil Tes Diagnosis Muhammad

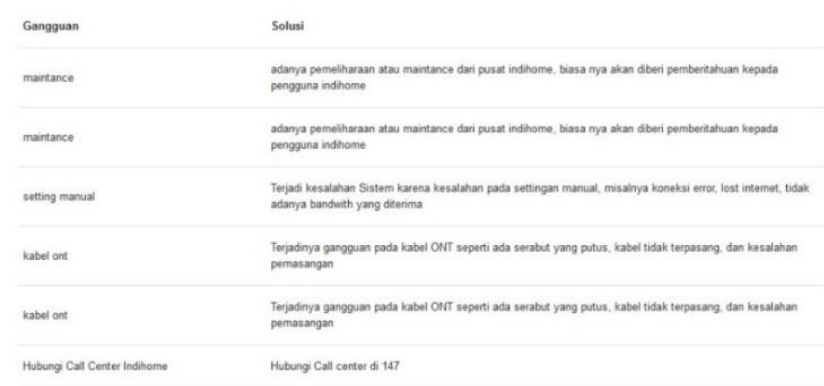

Gambar 7. Hasil historis konsultasi

4. Halaman Login Admin

Halaman Admin digunakan admin untuk menginput data diagnosa atau solusi dari gangguan pada Jaringan. Berikut adalah tampilan Login Admin. Untuk masuk harus menginput data username dan password. Tampilan halaman user dapat dilihat pada Gambar 8 berikut.

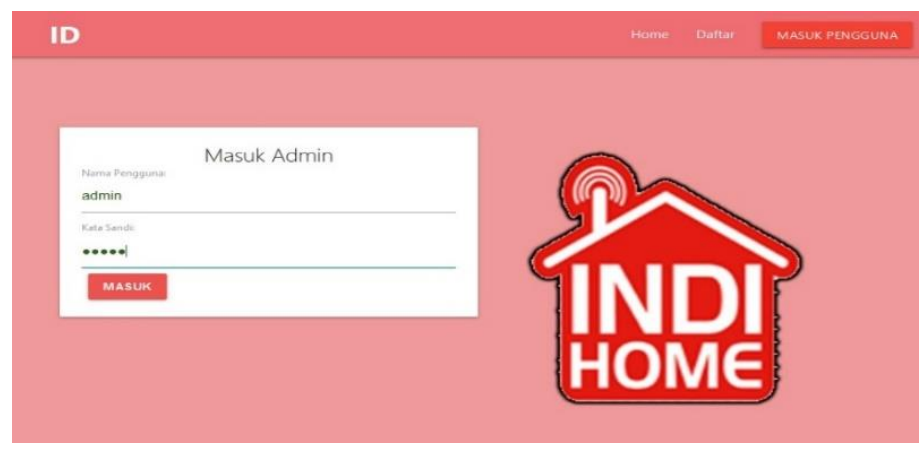

Gambar 8. Halaman Login Admin

\section{Halaman Beranda Admin}

Setelah berhasil login Admin akan masuk ke halaman beranda, dan di dalam halaman beranda terdapat beberapa sub menu yang dapat digunakan admin untuk menginput data diagnosa dan solusi. Berikut gambar tampilan halaman beranda Admin.

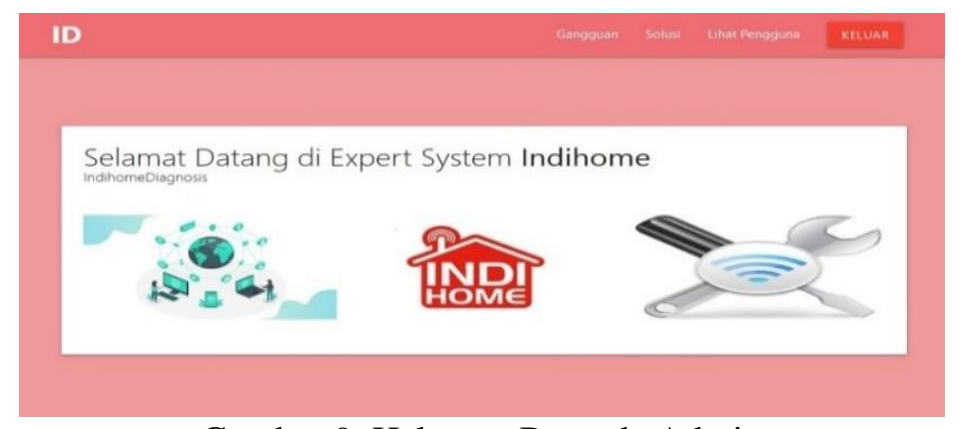

6. Halaman Input data Gangguan

Gambar 9. Halaman Beranda Admin

Sesudah berhasil login Admin akan berada di halaman beranda, dan di dalam halaman beranda terdapat sub menu input data gangguan yang bisa digunakan admin untuk menginput data jenis gangguan yang sering dialami oleh user jaringan indihome. Berikut gambar tampilan pada halaman input gangguan dapat dilihat di Gambar10 dibawah ini. 


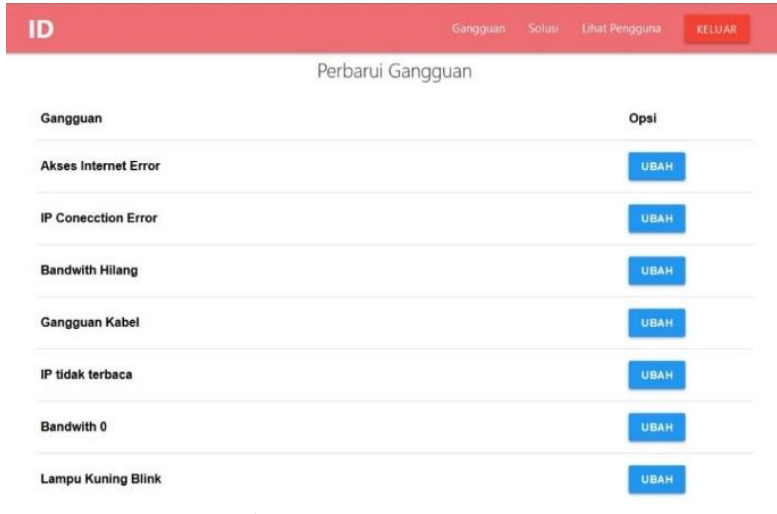

Gambar 10. Input Gangguan

7. Halaman Input Data Solusi

Sesudah berhasil login Admin akan masuk ke halaman beranda, dan di dalam halaman beranda terdapat sub menu input solusi yang dapat digunakan admin untuk menginput data solusi dari gangguan yang sering dialami oleh user jaringan indihome. Berikut gambar tampilan halaman solusi dapat dilihat pada Gambar 11 dibawah ini.

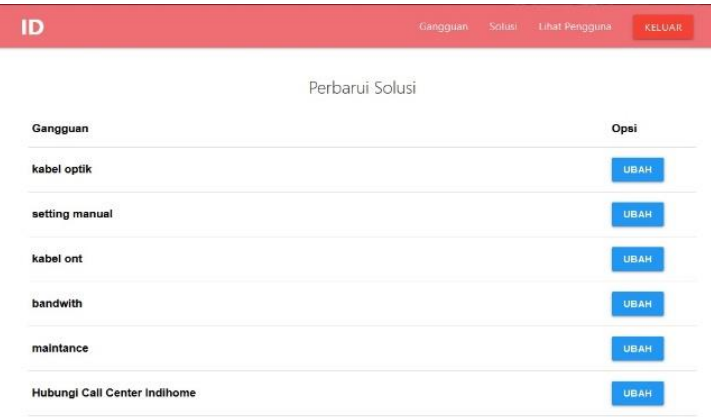

Gambar 11. Input Data Solusi

\section{KESIMPULAN}

Kesimpulan yang dapat diperoleh setelah implementasi Sistem Pakar Diagnosa gangguan pada Koneksi Internet Indihome menggunakan Metode Forward Chaining adalah Secara umum Sistem Pakar untuk Diagnosa gangguan pada Koneksi Internet Indihome memakai Metode Forward Chaining dengan bahasa pemrograman PHP telah berhasil. Sistem Pakar ini dapat digunakan dengan baik dalam memberikan konsultasi gangguan pada koneksi internet Indihome secara efisien dan efektif, memberikan informasi tentang gangguan, penyebab dan solusinya, serta pengelolaan data, untuk menghasilkan analisa hasil diagnose kerusakan jaringan sesuai dengan penyebab yang dikeluhkan user, dan juga Hasil output sistem pakar sudah sesuai dengan kebutuhan user pengunjung saat berkonsultasi.

\section{DAFTAR PUSTAKA}

[1] R. Rizky, A. H. Wibowo, Z. Hakim, and L. Sujai, "Sistem Pakar Diagnosis Kerusakan Jaringan Local Area Network (LAN) Menggunakan Metode Forward Chaining," J. Tek. Inform. Unis, vol. 7, no. 2, pp. 145-152, 2020, doi: 10.33592/jutis.v7i2.396.

[2] S. Saiful Rizal/Rini Agustina, "Sistem Pakar Diagnosa Kerusakan Komputer dengan Metode Forward Chaining dan Certainty Factor di Universitas Kanjuruhan Malang," Bimasakti, 2014.

[3] H. Hafizah, T. Tugiono, and A. Azlan, "Sistem Pakar Untuk Pendiagnosaan Karies Gigi Menggunakan Teorema Bayes," J-SISKO TECH (Jurnal Teknol. Sist. Inf. dan Sist. Komput. TGD), vol. 4, no. 1, p. 103, 2021, doi: 10.53513/jsk.v4i1.2625.

[4] R. E. Putri, K. Molly Morita, and Y. Yusman, "Penerapan metode forward chainig pada sistem 
pakar untuk mengetahui kepribadian seseorang," INTECOMS J. Inf. Technol. Comput. Sci., vol. 3, no. 1, p. 7, 2020.

[5] Refli Noviardi, "Sistem Pakar Berbasis Web Menggunakan Metode Forward Chaining Dalam Menganalisa Kerusakan Mesin Fotokopi Dan Penannggulangannya (Study Kasus Di Q-El Copier Service Center and Distributor)," JURTEKSI (Jurnal Teknol. dan Sist. Informasi), vol. 53, no. 9, pp. 163-172, 2020.

[6] H. Ismatullah and Q. J. Adrian, "Implementasi Prototype Dalam Perancangan Sistem Informasi Ikatan Keluarga Alumni Santri Berbasis Web,” J. Inform. Dan Rekayasa ..., vol. 2, no. 2, pp. 310, 2021.

[7] M. F. Mulya, Y. E. Wibawa, and A. L. B. Masalah, "Aplikasi Sistem Personalisasi Dan Monitoring Pengunjung Berbasis Smartcard RFID ( Radio Frequency Identification ) Studi Kasus Candi Borobudur," vol. V, no. September, pp. 1-10, 2021.

[8] A. H. Nugroho and T. Rohimi, "Perancangan Aplikasi Sistem Pengolahan Data Penduduk Dikelurahan Desa Kaduronyok Kecamatan Cisata, Kabupaten Pandeglang Berbasis Web," Jutis, vol. 8, no. 1, pp. 17749231-5527063, 2020.

[9] M. F. Yuliandi, "PEMBUATAN APLIKASI PENGARSIPAN PETA PERTANAHAN SECARA DIGITAL MENGGUNAKAN PHP FRAMEWORK DAN MySQL DI KANTOR PERTANAHAN KOTA BANDAR LAMPUNG," SEKOLAH TINGGI PERTANAHAN NASIONAL YOGYAKARTA, 2013.

[10] T. Istanto, F. X. Manggau, and L. Lamalewa, "IMPELEMENTASI OWNCLOUD PADA JURUSAN TEKNIK INFORMATIKA,” vol. 10, no. 2, pp. 47-51, 2021. 